\title{
PREFACE FROM THE EDITOR
}

In this volume, we have some excellent papers about the applications, development, and history of the radiocarbon method. I have been thinking for some time about how to introduce this volume commemorating 50 years of our journal, Radiocarbon. In doing so, I found myself reflecting on how I came to be involved in the field in the first place, and also reviewed some historical documents in the Radiocarbon editor's office. Intriguingly, the first editor, Ed Deevey, left a large box of early correspondence, labeled "important" in red letters, for posterity. I have the feeling he knew that these documents would one day be of further use.

First, I should explain how I came to be the editor of Radiocarbon. It seems like most things, that unpredicted and accidental interactions are of great importance. In 1979, I was a postdoctoral fellow at the University of Cambridge and had just decided to move on to another such position in the MaxPlanck Institute in Mainz. I had the opportunity to obtain a small travel grant and attended an Ion Beam Analysis (IBA) Conference in Aarhus in 1979. As luck would have it, an interesting presentation on a novel method of radiocarbon dating by accelerator mass spectrometry (AMS) was made at this conference by Harry Gove, who recently passed away. Indeed, Gove writes in his book "I attended the IV International Conference on Ion Beam Analysis held in Aarhus, Denmark, from 2529 June 1979 and presented our AMS work on 27 June" (Gove 1996). This sparked my first interest in the field. Later, after some time in Germany, I was offered a position at the University of Arizona in 1981 in this newly-developing field of AMS. I met many interesting colleagues and learned many interesting things since that time. I learned that the field of radiocarbon had originated in the late 1940s through the work of Arnold, Anderson, and Libby and that Libby had obtained the Nobel Prize. I also learned the long, complex history of the field from some of my colleagues at Arizona, particularly Paul Damon and Austin Long, and of accelerator methods from Doug Donahue. The first Radiocarbon Conference I attended was the one in Seattle, in 1982. I recall that the AMS scientists were considered with some reserve, if not disdain, by the older practitioners of the field, who used counters, and we were basically relegated to the rear of the lecture hall.

On 1 January 1989, the journal was moved from its original location at Yale University, to Tucson, with Austin Long as editor and Renee Kra as managing editor. The University of Arizona became the owner of this prestigious journal. After 10 years of service, Austin retired in 1999 and passed on the editorship to me. I recall being asked by the department head if I wanted the position, and being somewhat reticent to accept it. However, I have no regrets about taking on this interesting task. It is hard to believe this was 10 years ago.

I have recently been reviewing some of the early history of the field, through Deevey's correspondence and remarkable collection of early papers. His notes include Libby's first papers (see Figure 1), hand-written notes, extensive correspondence with various luminaries in the field, and digressions into administrative minutiae, of the kind that annoy university faculty to this day. Deevey provided some of the early samples measured by Libby. In one letter, Libby writes to $\mathrm{Dr} \mathrm{H}$ Godwin at Cambridge: "Dr. Deevey wrote me some time ago saying that you might like your samples back if we had no intention of making further measurements with them" (Letter of Libby to Godwin, 4 December 1950).

The world of 1951, the year I was born, was the year of the first radiocarbon date list (Arnold and Libby 1951). At that time, Ed Deevey had received a grant to set up a Radiocarbon Laboratory at Yale University. Initially, ${ }^{14} \mathrm{C}$ dates were a novel idea and would be published in journals like Science and Nature. It would be some time before the idea of a Radiocarbon journal, first as a supplement to the American Journal of Science, would take shape. Indeed, in the first issue of the journal 

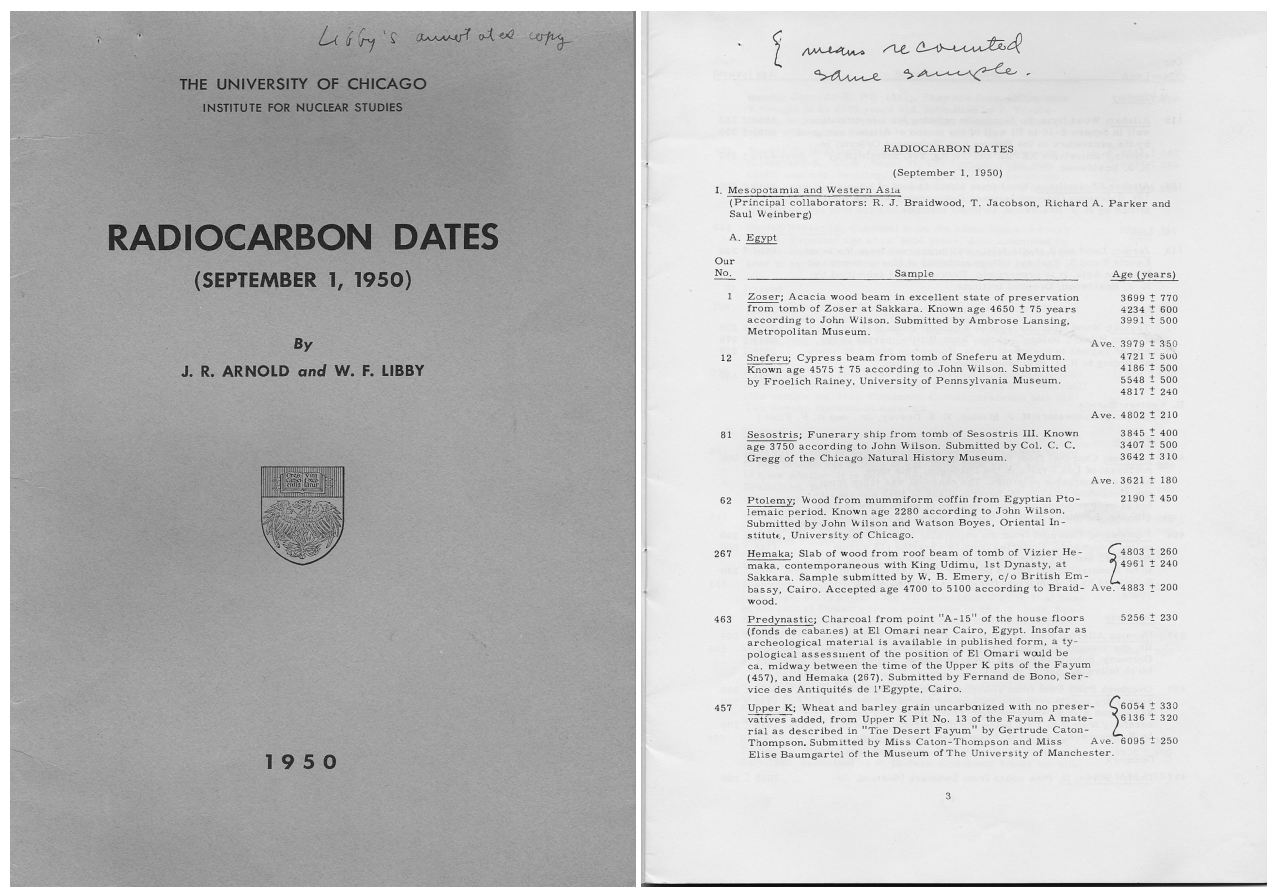

Figure 1 Libby's annotated copy of Arnold and Libby (1950)

Radiocarbon in 1959, the first paper is by an author in this issue, Wally Broecker (Broecker and Olson 1959; Olson and Broecker 1959). Their letter to Deevey is shown in Figure 2.

Let me return to Deevey's early laboratory. He notes in a letter of 27 January 1951 that "as you probably know, Yale is about to embark on a continuation of the radiocarbon dating program. This project is sponsored for the time being by the Rockefeller Foundation, and consists of a laboratory, of which I am the director and general office boy, and an advisory board under the chairmanship of R. F. Flint." On 19 February 1951, Deevey wrote to his colleague, Richard Foster Flint, about the possibility of hiring an Austrian by the name of H E Suess. He opined further that "only a European is likely to be both good and willing to work for as little as $\$ 5000$," even though it was more than Deevey himself was paid. Deevey received a 1-word telegram in reply "Concur" on 26 February (Figure 3).

Eventually, Suess declined the offer and went to work for the US Geological Survey for $\$ 7600$ a year. There is much interesting discussion between various early ${ }^{14} \mathrm{C}$ practitioners about both technical details but also about various personnel matters. Deevey also appears to have managed to engender the wrath of his administration, for example, where he had charged the university $\$ 99.38$ for a trip to Ohio:

"Dear Mr. Deevey,

I fear it was not made clear that the University Travel Fund can be drawn on only to pay railroad fares to and from the professional meetings. This office is required to make its recommendations for reimbursement in conformity with this ruling..." (Letter to Deevey from E. S. Furniss, Provost, May 1952). 


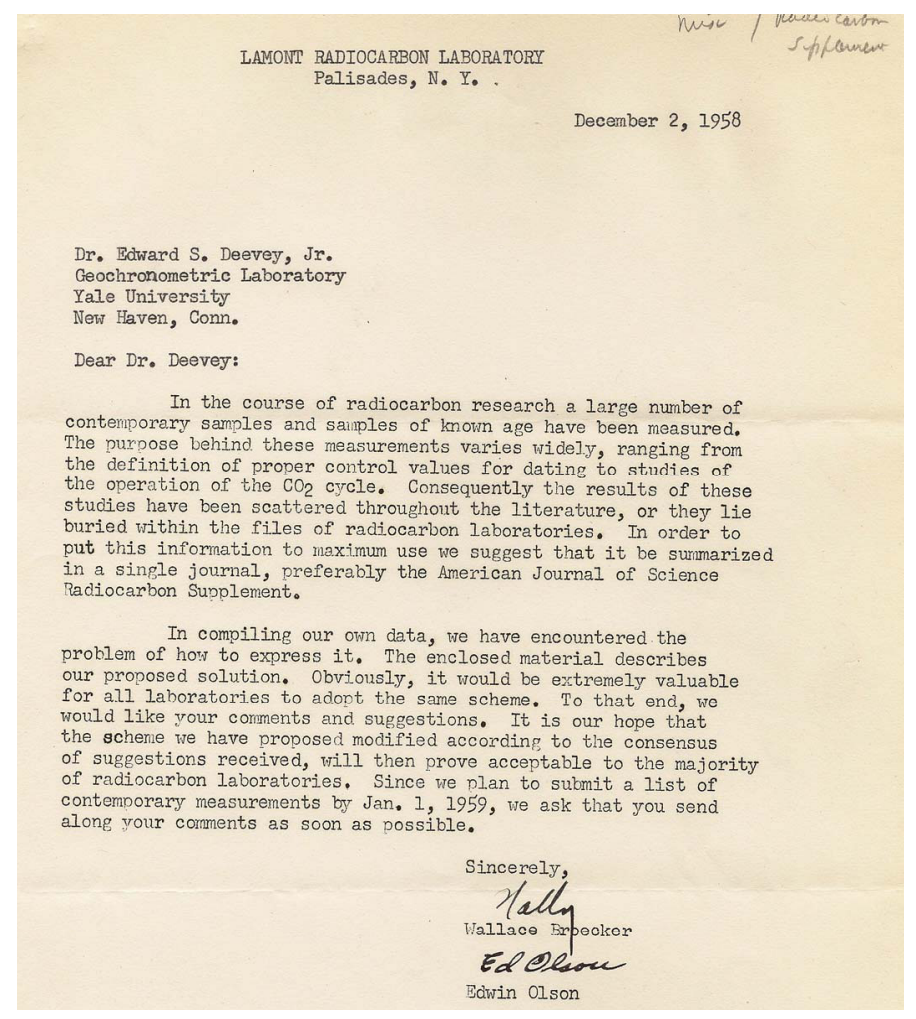

Figure 2 Broecker and Olson cover letter to Editor E S Deevey, 2 December 1958

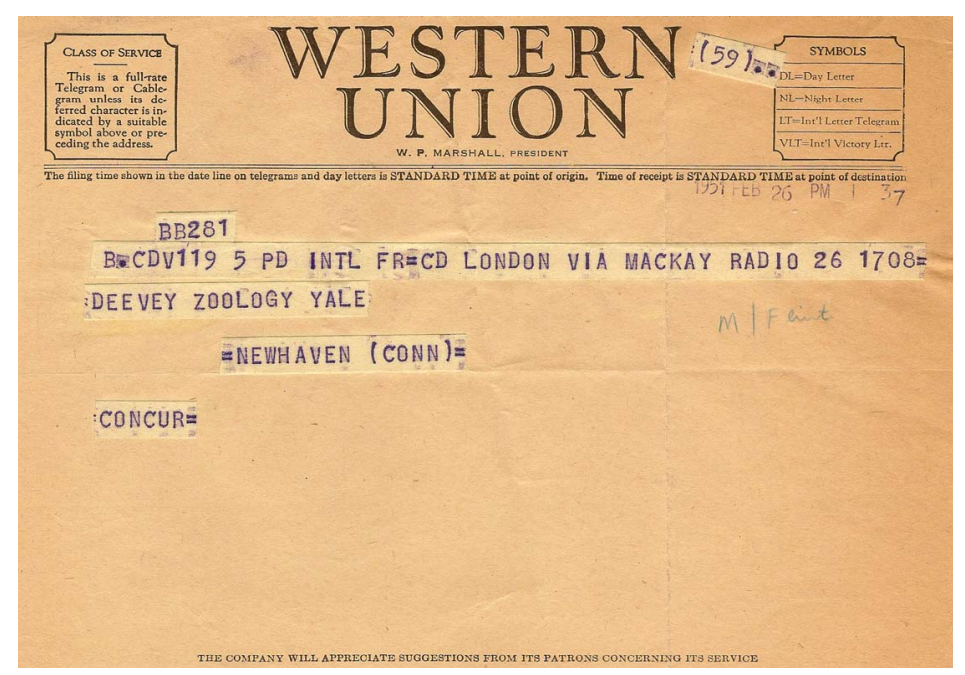

Figure 3 Telegram from E S Deevey to R F Flint, 26 February 1951

At other times, there were annoying letters from the Comptroller's Office about "disallowed items" on government contracts. There were also technical problems: 
In a letter to a German scientist in 1954, Deevey notes the problems with the original Libby "solid carbon" counting method had to be abandoned in favor of the new acetylene counting method of Suess. "Contamination by atomic bombs has delayed our whole program by two or three years, and we have to ask many collaborators all over the world to be patient" (22 December 1954).

In another: "I am sorry to report that we have had a complete instrumental breakdown, and it looks as though we will be out of action for the next two weeks at least" (30 October 1958).

In 1959, Deevey writes to Richard Foster Flint about an extensive trip Flint will make to various European laboratories (4 August 1959). Some excerpts: "I think you'll find Münnich, of Heidelberg, one of the most interesting to talk to, but practically all the labs are using DeVries's methods now and so perhaps only one Scandinavian lab is necessary - Trondheim could certainly be omitted... Bern is a real tour-de-force..."

So, it seems although many things have changed, many things also remain the same about the interactions between scientists. Deevey didn't get on too well with Libby. In a letter to his dean on 2 February 1953 , he writes:

"I am not very happy about the suggestion of Professor Libby as a Silliman lecturer. He has the "big operator' cast of mind that seems to characterize so many graduates of the Manhattan District, and of course he has made several brilliant discoveries; I have no doubt that he will grow to equal his own opinion of himself."

So, one has to ask: Why did Deevey store this correspondence for over 50 years for a future editor to read it? What will the current editor leave for the next 50 years?

I hope you will enjoy reading this issue, and congratulations for over 50 years of Radiocarbon, to all who have contributed. This issue would not have been possible without the time and effort volunteered by members of our editorial board.

\section{A J Timothy Jull}

Editor

\section{REFERENCES}

Arnold JR, Libby WF. 1950. Radiocarbon Dates (September 1, 1950). University of Chicago, Institute for Nuclear Studies.

Arnold JR, Libby WF. 1951. Radiocarbon dates. Science 113:111-20.

Broecker WS, Olson EA. 1959. Lamont radiocarbon measurements VI. American Journal of Science Ra- diocarbon Supplement 1:111-32.

Gove HE. 1996. The Shroud of Turin: Relic, Icon or Hoax? Bristol: Institute of Physics Publishing.

Olson EA, Broecker WS. 1959. Lamont radiocarbon measurements V. American Journal of Science Radiocarbon Supplement 1:1-28. 